\title{
A Rare Complication of Respiratory Syncytial Virus: Pneumomediastinum
}

\section{Solunum Sinsityal Virüsün Nadir Bir Komplikasyonu: Pnömomediastinum}

\author{
Osman Yeşilbaşs ${ }^{1}$ Ela $\mathrm{Cem}^{2}$, Gülşen Akkoç̧ \\ ${ }^{1}$ Pediatric Intensive Care Unit, Van Training and Research Hospital, Van, Turkey \\ ${ }^{2}$ Clinic of Pediatrics, Van Training and Research Hospital, Van, Turkey \\ ${ }^{3}$ Clinic of Pediatric Infectious Diseases, Van Training and Research Hospital, Van, Turkey
}

One-year-old previously healthy male patient was referred to our pediatric intensive care unit due to respiratory failure. On auscultation, there were decreased heart sounds and inspiratory crackles. Complete blood count, procalcitonin and C-reactive protein levels were within normal limits. Chest radiography showed air outlining the mediastinum (Figure 1, arrows) and paracardiac infiltrations. In the thorax computed tomography, pneumomediastinum (Figure 2, arrows) and bilateral basal lung infiltrates (Figure 2, stars) were detected. On the second day, respiratory distress worsened despite high-flow nasal cannula and he was intubated because of pediatric acute respiratory distress syndrome (PARDS). Repetitive blood and tracheal aspirate cultures were negative. A nasopharyngeal swab sample was analyzed by multiplex real-time polymerase chain reaction method with the use of viral respiratory panel and positive result was detected for only respiratory syncytial virus (RSV). On the $14^{\text {th }}$ day, he was discharged after pneumomediastinum and PARDS improved completely.

RSV is the most common viral etiological agent of bronchiolitis and viral pneumonia. Spontaneous pneumomediastinum secondary to RSV infection is extremely rare, and there are only a few case reports in the current literature $(1,2)$. It should not be forgotten that RSV can cause PARDS and it can be complicated with spontaneous pneumomediastinum.

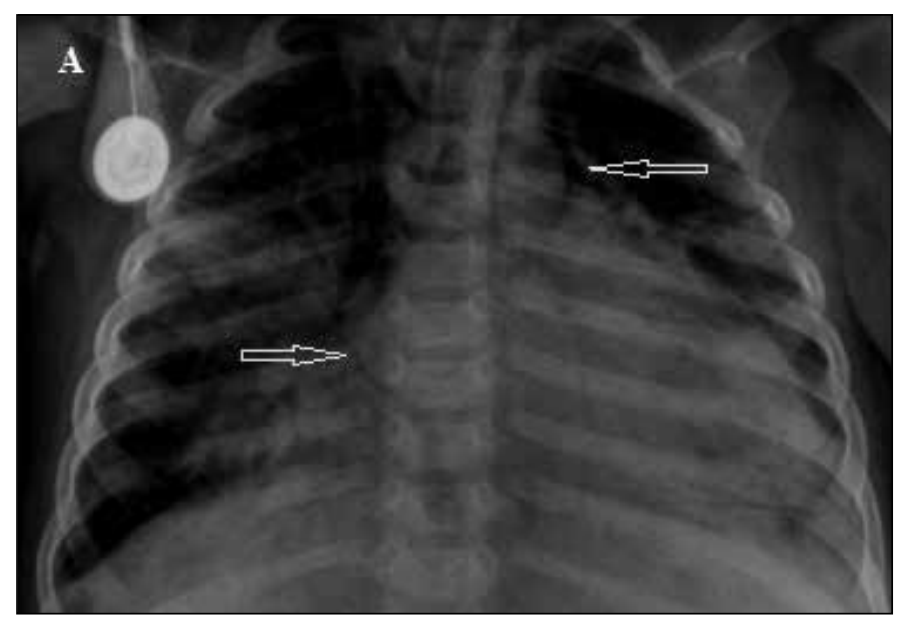

Figure 1. Chest radiography showed air outlining the mediastinum (arrows) and paracardiac infiltrations. 


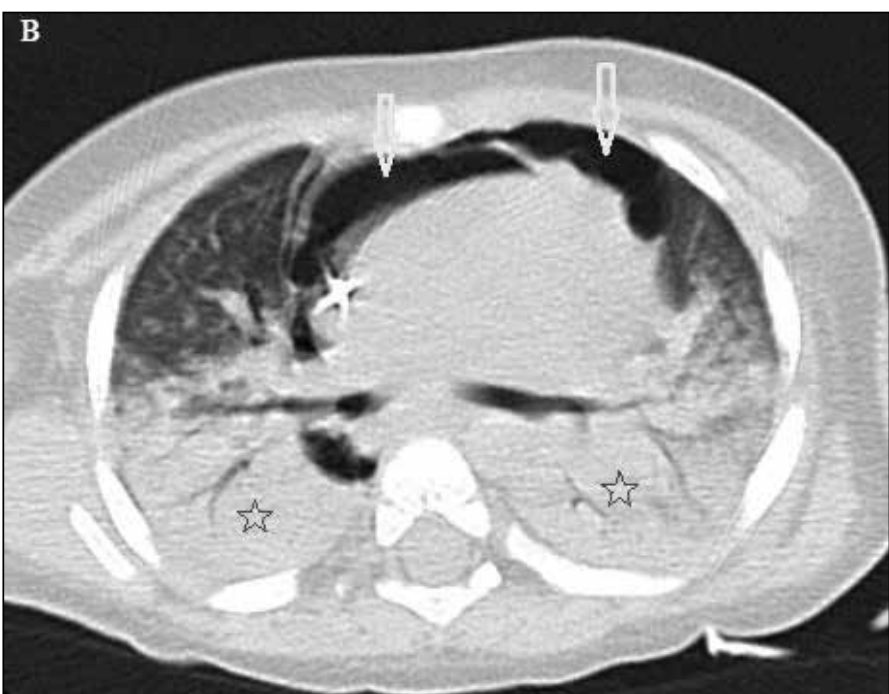

Figure 2. Thorax computed tomography. Pneumomediastinum (arrows) and bilateral basal lung infiltrates (stars).

\section{References}

1. Fantacci C, Ferrara P, Franceschi F, Chiaretti A. Pneumopericardium, pneumomediastinum, and pneumorrachis complicating acute respiratory syncytial virus bronchiolitis in children. Eur Rev Med Pharmacol Sci 2017;21:3465-8.

2. Dehmel M, Demirakca S, Jordan A, et al. Pneumomediastinum and subcutaneus emphysema - an uncommon presentation of respiratory-syncytial virus infection in an infant. Klin Padiatr 2013;225:230-1. 